\title{
Fenomena Calo Liar
}

\author{
Muhammad Rizal ${ }^{1}$, Syaribulan $K^{2}$, Sitti Fatimah Tola ${ }^{3}$ \\ ${ }^{1}$ Pendidikan Sosiologi, Universitas Muhammadiyah Makassar \\ Email: muhammadrizal@gmail.com \\ ${ }^{2}$ Pendidikan Sosiologi, Universitas Muhammadiyah Makassar \\ Email:syaribulan@unismuh.ac.id \\ ${ }^{3}$ Pendidikan Sosiologi, Universitas Muhammadiyah Makassar \\ Email: sittifatimahtola@unismuh.ac.id
}

\begin{abstract}
Wild brokers or commonly known as car agents are jobs that offer services to passengers to be transported to a car that aims at the passenger area. The purpose of this study was (i) to know the motivating factors for someone working as a wild broker, especially brokers in the power terminal of the city of Makassar. (ii) This study also aims to determine the impact that is generated by the presence of brokers at the Makassar City Power Terminal. This study used descriptive qualitative method. Target in the research of all brokers inside and outside the terminal, passengers, terminal officers and car drivers. The sample chosen was 4 brokers, 4 terminal officers, 3 passengers and 4 car drivers. Sampling in this study was taken by using interview techniques. The results of the study showed that the difficulties in getting a job, urbanization factors, and economic factors became the basis for someone working as a broker. With the presence of brokers at the Makassar city power terminal it turned out to provide a loss to the passengers, car drivers and terminal officers.
\end{abstract}

Keywords: Brokers, Terminals, Social Deviations.

\begin{abstract}
Abstrak: Calo liar atau biasa dikenal dengan sebutan agen mobil merupakan sutau pekerjaan yang menawarankan jasa kepada penumpang untuk di carikan mobil angkutan yang bertujuan ke daerah yang diingan penumpang tersebut. Tujuan penelitian ini adalah (i) mengetahui faktor pendorong seseorang bekerja sebagai calo liar, khususnya para calo yang berada di terminal daya kota Makassar. (ii) Penelitian ini pula bertujuan untuk mengetahui dampak yang di hasilkan dengan adanya calo di Terminal Daya Kota Makassar. Penelitian ini menggunakan metode deskriptif kualitatif. Sasaran dalam penelitian seluruh calo yang berada di dalam dan di luar terminal, penumpang, petugas terminal dan sopir mobil. Adapun sampel yang dipilih sebanyak 4 orang calo, 4 orang petugas terminal, 3 orang penumpang dan 4 orang sopir mobil. Penarikan sampel dalam penelitian ini ditempuh dengan menggunakan teknik wawancara. Hasil penelitian menunjukan bahwa factor kesulitan mendapatkan pekerjaan, factor urbanisasi, dan factor ekonomi menjadi dasar seseorang bekerja sebagai calo. dengan keberadaanya para calo di terminal daya kota makassar ini ternyata memberikan kerugian terhadap para penumpang, sopir mobil dan petugas terminal.
\end{abstract}

Kata Kunci : Calo, Terminal, Penyimpangan Sosial.

\section{PENDAHULUAN}

Dalam kehidupan masyarakat sering dijumpai adanya perilaku yang menyimpang. Perilaku menyimpang merupakan hasil dari proses sosialisasi yang tidak sempurna. Perilaku yang menyimpang mengakibatkan terjadinya pelanggaran. Pelanggaran tersebut terjadi 
karena seorang individu atau kelompok tidak bisa bersosialisasi secara sempurna. Hal tersebut menyebabkan individu atau kelompok terjerumus ke dalam pola perilaku yang menyimpang. Dengan kata lain, terjadilah penyimpangan sosial dalam kehidupan, Dengan kata lain, penyimpangan adalah tindakan atau perilaku yang tidak sesuai dengan norma dan nilai yang dianut dalam lingkungan baik lingkungan keluarga maupun masyarakat yang menghasilkan gaya hidup. Gaya hidup dipahami sebagai strategi seseorang dalam memanfaatkan benda-benda tertentu atau apa saja, dalam rangka usaha untuk mendapatkan status sosialnya. Sehingga selanjutnya ia akan diperlakukan oleh orang lain sesuai dengan level dari status yang ia capai, seperti halnya gaya calo liar yang ada di terminal. Terminal merupakan komponen penting dalam sistem transportasi. Terminal penumpang merupakan prasarana transportasi jalan untuk menurunkan dan menaikkan penumpang, perpindahan intra atau antar moda transportasi serta mengatur kedatangan dan pemberangkatan kendaraan umum.

Terminal Regional Daya adalah terminal terbesar di Kota dan terletak 15 km dari pusat Kota Makassar. Keberadaannya sangat vital dalam memberikan kontribusi bagi efisiensi perjalanan masyarakat Kota Makassar (dalam penggunaan moda angkutan umum) dan sumbangan kepada pendapatan asli daerah (PAD). Pengelolaan Terminal Regional Daya diserahkan sepenuhnya kepada suatu Perusahaan Daerah (PD) di bawah naungan pemerintah Kota Makassar. Pelimpahan pengelolaan terminal kepada pihak perusahaan daerah adalah sebagai upaya dalam penigkatan profesionalisme manajemen pengolaan terminal, namun sejumlah permasalahan yang nampak berdasarkan hasil observasi pendahuluan di lapangan terkait dengan penurunan fungsi terminal regional daya adalah sirkulasi kendaraan dalam terminal yang cendrung bercampur, termasuk pula penyalah gunaan fungsi ruang parkir dan kurangnya pengawasan petugas terhadap aktivitas terminal, yang mana keberadaan petugas lebih terfokus pada urusan penarikan retribusi. Dengan adanya sejumlah permasalahan tersebut membuat masyarakat setempat melakukan pengumutan liar (calo liar), karena kebanyakan penumpang daerah lebih memilih menunggu mobil di luar terminal daya yakni terminal bayangan sepanjang jalan perintis kemerdekaan. 


\section{LANDASAN TEORI}

Menurut (Waluyo,2011:18) fenomena adalah rangkaian peristiwa serta bentuk keadaan yang dapat diamati dan dinilai lewat kaca mata ilmiah atau lewat disiplin ilmu tertentu. (Waters, 1994:30) aliran fenomena lahir sebagai reaksi metodologi positivistic yang diperkenalkan Comte. Pendekatan positivisme selalu mengandalkan seperangkat fakta social yang bersifat objektif, atas gejala yang tampak secara kasatmata. Fenomena sebagai aliran Filsafat sekaligus sebagai metode berpikir diperkenalkan oleh Edmund Husserl, yang beranjak dari kebenaran, seperti yang tampak apa adanya. Suatau fenomena yang tampak sebenarnya yang merupakan frefleksi realitas yang tidak berdiri sendiri, karena yang tampak itu adalah objek yang penuh dengan makna yang transendental (Hadiwiyo,1985:139). Menurut Bogdan dan Taylor, (Orleans,2000:159) Fenomena harus menggunakan metode kualitatif, dengan melakukan pengamatan partisipan, wawancara yang intensif (agar mampu menyelami orientasi subjek atau dunia kehidupanya) melakukan analisis dari kelompok kecil, dalam memahami keadaan social. Bahkan menurut Leiter, maupun menurut mehan dan Wood (Orleans,2000:164) peneliti harus mampu membuka selubung peraktik yang di gunakan oleh orang yang melakukan kehidupan sehari-hari. Hal ini penting agar mengetahui bagaimana rutinitas itu berlangsung.

Fenomena perilaku menyimpang dalam kehidupan bermasyarakat memang menarik untuk dibicarakan. Sisi yang menarik bukan saja karena pemberitaan tentang berbagai perilaku manusia yang ganjil itu dapat mendongkrak oplah media massa dan rating dari suatu mata acara distasion televisi, tetapi juga karena tindakan-tindakan menyimpang dianggap dapat menggangu ketertiban masyarakat. Kasus-kasus pelanggaran norma sosila dan berbagai tindakan criminal yang ditanyakan oleh berbagai stasion televisi, atau gosipgosip gaya hidup selebriti yang terkesan jauh berbeda dengan kehidupan nyata masyarakat, meskipun dicari penontonya karena dapat memenuhi hasrat ingin tahu mereka, juga sering kali dicaci karena perilaku yang dianggap tak layak.

Perilaku menyimpang adalah perilaku dari para warga masyarakat yang dianggap tidak sesuai dengan kebiasaan, tata aturan atau norma social yang berlaku. Secara sederhana kita memang dapat mengatakan, bahwa seseorang berperilaku menyimpang apabila menurut anggapan sebagian masyarakat (minimal disuatu kelompok atau komunitas 
tertentu) perilaku atau tindakan tersebut diluar kebiasaan, adat istiadat, aturan nilai-nilai, atau norma sosial yang berlaku.

Menurut Narkowo dan bagong suyanto(2011:99) tindakan menyimpang yang dilakukan orang-orang tidak selalu berupa tindakan kejahatan besar, seperti merampok, korupsi, menganiaya, atau membunuh. Melainkan bisa pula Cuma berupa tindakan pelanggaran kecil-kecilan, semacam berkelahi dengan teman, suka meludah disembarang tempat, berpacaran hingga larut malam, makan dengan tangan kiri dan sebagainya. Menurut (Clinard dan Meier, 1989:4-7), defenisi tentang perilaku menyimpang yang di kemukakan di sini adalah hasil rumusan para ahli yang telah melakukan studinya di berbagai kelompok masyarakat. Berdasarkan studi-studi tersebut, maka perilaku menyimpang dapat didefinisikan seperti yang di jelaskan Becker (dalam Clinard dan Meier,1989:5), penyimpangan adalah sesuatu akibat yang kepada siapa cap itu telah berhasil diterapkan, perilaku menyimpang adalah perilaku yang dicapkan kepadanya atau orang lain telah memberi cap kepadanya. Menurut (Mujtaba, 2007: 239) Dalam kamus besar bahasa Indonesia, calo liar berarti orang yang menjadi perantara dan memberikan jasanya berdasarkan upah.

Calo liar bisa disamakan dengan makelar atau perantara dalam hal ini calo liar dapat diartikan dengan perantara perusahaan pemberi jasa transportasi dan pengguna jasa. Calo liar adalah seseorang atau sebuah badan perusahaan yang menjadi pihak tengah dalam suatu urusan. Di Indonesia, Perantara lebih dikenal dengan kata "calo liar" yang sebetulnya memiliki arti beda secara maknanya. Oleh karena kesalahan persepsi tersebut, jasa perantara tidak terlalu banyak berkembang di Indonesia karena menurut sebagian masyarakat "calo liar" adalah suatu pekerjaan yang kurang baik. Seperti yang di ungkapkan Ir. Muhsin R. Radjab sala satu petugas terminal bagian kabag umum dan pak Alexander sala seorang penumpang mobil, mengatakan keberadaan calo liar ini sebenarnya tidak memberikan keuntungan bagi pemerintah dan masyarakat terminal karena sikap dan tingkah laku mereka kebanyakan memberikan penyimpangan bagi masyarakat terminal khususnya para menumpang, karena dalam menawarkan jasa terhadap penumpang mereka sedikit memaksa. 


\section{METODE PENELITIAN}

Jenis penelitian yang dilakukan peneitian kualitatif yang bertujuan memahami realitas fenomenacalo liar (studi kasus perebutan penumpang mobil di terrminal daya kota makassar), yang terdapt di terminal daya kota Makassar. Informasi di tetntukan melalui teknik pengumpulan data yaitu observasi, wawancara dan dokumentasi, kemudian dianalisis melalui tahapan pengumpulan data (data collection), reduksi data (data reduction), penyajian data (display data), penarikan kesimpulan (conclusion) dan menggunakan teknik keabsahan data triangulasi sumber, teknik, dan waktu.

\section{PEMBAHASAN}

Dalam pembahasan mengenai gaya hidup menyimpang dalam kehidupan masyarakat, memang bukanlah fenomena yang sangat baru dibicarakan. Bahkan perilaku tersebut sudah ada sejak dulu kala. Membahas perilaku menyimpang memang tidak akan ada habisnya. Dalam proses melakukan penyimpangan, seesorang memulainya dengan melakukan penyimpangan kecil yang awalnya mungkian tidak disadari dan kemudian berkembang, dengan melakukan penyimpangan yang semakin lama semakin besar. Para pelaku penyimpangan tidak selalu melanggar norma, mereka biasanya melanggar satu norma namun mematuhi norma yang lain. Yang menjadi hal yang patut dipertanyakan yaitu, mengapa dalam kehidupan manusia perilaku dengan gaya hidup menyimpang sebagai dasarnya masih saja terus ada, walaupun dalam kehidupan masyarakat terdapat tatanan nilai dan norma yang mengatur kehidupan perilaku bagi setiap manusia.

Sebenarnya, titik permasalahan yang mendasari terjadinya perilaku menyimpang adalah cara manusia dalam mencapai tujuan dan kehendak dalam proses pencapaian pemuasan dirinya. Sebab semua orang pastilah mempunyai tujuan dan ingin memuaskan diri sendiri, dan dalam prosesnya sering kali tidak didasari dengan tatanan nilai serta norma dalam pemenuhan kebutuhannya tersebut. Sebagian kelompok dalam masyarakat menganggap bahwa tatanan nilai dan norma yang ada dalam masyarakat merupakan pengekangan dan membatasi mereka dalam mencapai kebebasan dalam mencapai tujuan hidup. Hal ini yang kemudian menjadi faktor yang mendorong mereka melakukan 
penyimpangan dalam proses pemuasan kebutuhan hidup dan pencapaian tujuan dalam kehidupan mereka. Menurut para ahli teori labeling, mendefinisikan penyimpangan merupakan sesuatu yang bersifat relative dan bahkan mungkin juga membingungkan. Karena untuk memahami apa yang dimaksud sebagai suatu tindakan menyimpang yang harus diuji melalui reaksi orang lain. Oleh karena itu Becker, sala seorang pencetus teori labeling (dalam clinard dan meier,1989:92) mendefinisikan penyimpangan sebagai" suatu konsekuensi dari penerapan aturan-aturan dan sanksi oleh orang lain kepada seorang pelanggar". Melalui definisi itu dapat di tetapkan bahwa penyimpangan adalah tindakan yang dilabelkan kepada seseorang, atau pada siapa label secara khusus telah ditetapkan. Dengan demikin, dimensi penting dari penyimpangan adalah pada adanya reaksi masyarakat, bukan pada kualitas dari tindakan itu sendiri. Atau dengan kata lain, penyimpangan tidak ditetapkan berdasarkan norma, tetapi melaui reaksi atau sanksi dari penonton sosialnya. Konsekunsi dari pemberian label tersebut, terutama oleh aparat atau alat-alat Negara (polisi, jaksa, hakim), mungkin akan berakibat serius pada penyimpangan yang lebih lanjut. Inilah yang membedakan bentuk penyimpangan primer dengan penyimpangan sekunder, dimana penyimpangan menghasilkan suatu peran social yang menyimpang juga. Artinya, dengan adanya cap yang diletakan pada diri seseorang maka ia (yang telah di beri cap) cenderung mengembangkan konsep diri yang menyimpang (disebut juga sebagai proses reorganisasi psikologis) dan kemungkinan berakibat pada suatu karier yang menyimpang. Proses terjadinya penyimpangan sekunder membutuhkan waktu yang panjang dan tidak kentara. Contoh: ada seorang berperilaku sebagai homo seksual, demi uang pada tindakan itu ia lakukan dengan terpaksa. Namun, oleh karena masyarakat telah terlanjur memberinya cap (sebagai reaksi terhadap tindakanya itu), akibatnya dia akan menjadi homo seksual yang sesungguhnya.

\section{Faktor Seseorang Bekerja Sebagai Calo Liar.}

\section{a. Faktor Kesulitan Mendapatkan Pekerjaan}

seperti yang mereka pahami dalam mencari pekerjaan yang baik mesti memiliki keterampilan atau keahlian tersendiri sehingga untuk mendapatkan pekerjaan yang layak itu sulit bagi mereka, dilain sisi karena sekolah mereka hanya sebatas tingkat SD-SMP sehingga mereka merasa mungkin inilah pekerjaan yang pantas kami lakukan, hampir sebagian besar 
orang-orang yang bekerja sebagai calo liar mobil di terminal regional daya berumur 35 sampai 50 tahun yang kurang lebih berjumlah 50 calo liar.

\section{b. Faktor Urbanisasi}

Sebagaimana kita ketahui bahwa di Indonesia banyak terjadi urbanisasi. Perpindahan penduduk mengakibatkan bermacam-macam dampak bagi masyarakat setempat (pribumi) dan masyarakat baru (pendatang). Tindakan masyarakat berpindah dari desa ke kota didasarkan atas harapan pelaku urbanisasi itu sendiri untuk mengubah perekonomian ke keadaan yang lebih baik. Jiwa atau ide yang mendorong perpindahan ke kota disebut urbanisme. Urbanisme menjadi motivasi manusia untuk berpindah ke kota, dan urbanisme tersebut menimbulkan penambahan jumlah penduduk kota yang terus meningkat. Dalam hal ini urbanisme adalah proses perpindahan ke kota dan urbanisme merupakan ide abstrak yang terwujud di dalam kesadaran yang berorientasi ke kota. Dengan adanya urbanisasi maka semakin banyak tenaga kerja untuk mendapatkan pekerjaan. Mereka tergolong dalam golongan pencari kerja dengan berbagai macam latar belakang pendidikan, pengalaman dan keahlian yang berbeda-beda. Peningkatan jumlah para pencari kerja dan urbanisasi di Indonesia berhubungan dengan masalah pengangguran. Masalah pengangguran oleh banyak pihak diungkapkan sebagai akibat keterbatasan lapangan pekerjaan, pendidikan yang rendah dan keterampilan yang kurang dari para pencari kerja. Masalah ketenaga kerjaan di Indonesia bukan hanya terfokus pada keterbatasan lapangan pekerjaan, keterbatasan pendidikan dan keterampilan, tetapi tidak terpenuhinya lowongan-lowongan pekerjaan difaktorkan tidak tersedianya tenaga-tenaga kerja yang berkualitas. Masalah tenaga kerja berkualitas menjadi penting untuk diperhatikan, untuk meningkatkan kinerja tenaga kerja tersebut, karena masalah ini menyangkut kepentingan perusahaan-perusahaan sebagai pengguna tenaga kerja dan penyedia lapangan kerja. Ternyata perusahaan telah banyak membuka banyak kesempatan kerja, tetapi fakta yang dihadapi oleh perusahaan adalah kesulitan untuk mencari tenaga kerja yang sesuai dengan kualifikasi perusahaan. Karena kekurangan tingkat pendidikan dan keterampilan yang dimiliki para pencari kerja maka sulit baginya untuk mendapatkan pekerjaan. Berangkat dari hal tersebut tidak sedikit masyarakat urban yang mengubah pekerjaannya menjadi agen atau calo liar, dengan alasan sebagai batu loncatan untuk menyambung hidup di kota besar. 


\section{c. Faktor Kesulitan Ekonomi}

Orang-orang yang mengalami kesulitan ekonomi dan kerugian harta yang cukup besar membutuhkan bantuan orang lain. Contoh, para pedagang yang jatuh bangkrut, atau para petani yang gagal panen secara total, dan lain sebagainya. Mereka ini juga memerlukan bantuan karena sedang mengalami kesulitan ekonomi secara mendadak sehingga tidak bisa menghidupi kebutuhan keluarga. Faktor-faktor kesulitan ekonomi yang muncul akibat tidak seimbangnya antara penghasilan sehari-hari yang didapat dengan besarnya nafkah yang harus dikeluarkan untuk memenuhi kebutuhan hidup sehari-hari anggota keluarga yang berjumlah banyak. Sesuai dengan penjelasan dalam Teori Pertukaran Sosial secara garis besar George C. Homans dalam Elbadiasyah (2014: 55) menyusun lima proposisi dari teori ini, diantaranya yaitu Semakin sering individu melakukan suatu tindakan tertentu yang dinilainya membawa keuntungan atau manfaat, maka semakin sering individu tersebut akan melakukan tindakan yang sama. Dari hasil penelitian yang telah didapatkan, maka penulis menyimpulkan bahwa beberapa factor pendorong seseorang bekerja sebagai calo liar adalah factor kesulitan mendapatkan pekerjaan yang didasari dari factor ekonomi, tidak hanya itu sebagian besar dari mereka pun berasal dari daerah yang berbeda-beda bukan hanya orang bugis Makassar. Dalam teori pertukaran social menjelaskan bahwa semakin seseorang melakukan tindakan tindakan maka yang membawa keuntungan pada dirinya, maka sering pula tindakan itu akan dilakukannya, kaitannya dengan kehidupan bagi pekerja sebagai calo liar yaitu persepsi sebagian besar dari mereka yang merasakan bahwa pekerjaan ini memberikan tambahan pendapatan dari pekerjaan tertsebut, dan juga para calo liar merasa nyaman dengan pekerjaan itu.

\section{Dampak yang dihasilkan dengan adanya calo liar terhadap penumpang, sopir mobil, dan Petugas Terminal.}

Pelimpahan pengelolaan terminal kepada pihak perusahaan daerah adalah sebagai upaya dalam peningkatan profesionalisme manajemen pengolaan terminal, namun sejumlah permasalahan yang nampak berdasarkan hasil observasi pendahuluan di lapangan terkait dengan penurunan fungsi terminal regional daya adalah sirkulasi kendaraan dalam terminal yang cendrung bercampur, termasuk pula penyalah gunaan fungsi ruang parkir dan kurangnya pengawasan petugas terhadap aktivitas terminal, yang mana keberadaan petugas lebih terfokus pada urusan penarikan retribusi. Dengan adanya sejumlah 
permasalahan tersebut membuat masyarakat setempat melakukan pengumutan liar (calo liar), karena kebanyakan penumpang daerah lebih memilih menunggu mobil di luar terminal daya yakni terminal bayangan sepanjang jalan perintis kemerdekaan, dengan adanya kesempatan seperti ini memaksa para calo liar melakukan kemampuan tersendirinya yang berbeda antara calo liar satu dengan calo liar yang lain, agar dalam proses perebutan penumpang itu mereka bisa dapatkan. Teori konflik lebih meniti beratkan analisisnya pada asal usul terciptanya suatu aturan atau tertib social. Teori ini tidak bertujuan untuk menganalisis asal usul terjadinya pelanggaran peraturan atau latarbelakang seseorang berperilaku menyimpang. Perspektif konflik lebih menekankan sikap pluralistic dari masyarakat dan ketidak seimbangan distribusi kekuasaan yang terjadi diantara berbagai kelompoknya. Karena kekuasaan yang dimiliki oleh kelompok-kelompok elit, maka kelompok-kelompok itu juga memiliki kekuasaan untuk menciptakan peraturan, khususnya hukum yang dapat melayani kepentingan-kepentingan mereka. Berkaitan dengan hal itu, prespektif konflik memahami masyarakat sebagai kelompok-kelompok dengan berbagai kepentingan yang bersaing dan akan cendrung saling berkonflik. Melalui persaingan itu, maka kelompok-kelompok dengan kekuasaan yang berlebih akan menciptakan hukum dan aturan-aturan yang menjamin kepentingan mereka di menangkan (Clinard dan meier,1989:98-99). Dari hasi pembahasan di atas, penulis dapat menyimpulkan bahwa keberadaan calo liar memberikan dampak negative dan positif terhadap petugas terminal, penumpang dan sopir mobil angkutan umum.

\section{a. Dampak Negatif}

Dengan adanya orang yang bekerja sebagai calo liar di terminal sebenarnya bagi para petugas terminal atau pemerintah tidak memberikan keuntungan sama sekali, malah memberikan kerugian yang cukup besar, dikarnakan mereka seenaknya saja mau berbuat di terminal seakan-akan terminal itu milik mereka. Sedangkan bagi para penumpang yang kami wawancarai, juga merasa keberadaan calo liar ini tidak memberikan keuntungan bagi mereka. Dan untuk sopir mobil angkutan umum ada yang sebagian merasa keberadaan calo liar ini membantu mereka tetapi ada juga merasa keberadaan calo liar ini tidak memberikan keuntungan bagi mereka. 


\section{b. Dampak positif}

Keberadaan calo liar di terminal daya kota Makassar memang memberikan banyak kesan bagi masyarakat yang ada di terminal, khususnya petugas terminal, penumpang dan sopir mobil angkutan umum. Bagi para sopir mobil angkutan umum khususnya mobil panter sebagainya hampir sebagian besar dari mereka merasa keberadaan calo ini membantu mereka dalam mencari penumpang, karna sebagian dari sopir berprinsif kehidupan calo liar dalam mencari nafka bergantung pada sopir mobil begitupun sebaliknya kehidupan para sopir mobil bergantung dari para calo liar. Karna para sopir merasa keberadan calo liar ini memberikan kemudahan bagi mereka dalam mencari penumpang. Sedangkan bagi para petugas terminal dan penumpang keberadaan calo ini tidak memberikan keuntungan bagi mereka.

\section{KESIMPULAN}

Adapun factor pendorong seseorang bekerja sebagai calo liar atau yang lebih di kenal dengan istilah aheng adalah sebagai berikut: a. Faktor kesulitan mereka mendapatkan pekerjaan selain dari pekerjaan calo liar. b. Faktor urbanisasi, Tindakan masyarakat berpindah dari desa ke kota didasarkan atas harapan pelaku itu sendiri untuk mengubah perekonomian yang lebih baik. c. Faktor kemiskinan/ekonomi untuk memenuhi kebutuhan hidup mereka.

Dampak adanya calo liar di terminal daya kota Makassar, dalam hal ini jelas membawa dampak negative dan positif sesuai dengan hasil penelitian yang di dapatkan di terminal daya kota Makassar, a. Dampak Negatif: 1) Mereka seenaknya saja melakukan pekerjaan di terminal daya kota Makassar tanpa merasa bahwa pengelolahan terminal regional daya kota Makassar itu di bawah naungan pemerintah daerah. 2) Keberadaan calo liar ini memberikan keresahan terhadap penumpang dan petugas terminal, karna dalam lelakukan pekerjaan mereka sebagai calo liar sedikit memaksa. b. Dampak positif: Sebagian besar dari sopir mobil angkutan umum khususnya mobil panther dan sejenisnya, dengan keberadaan calo liar ini memberiakn kemudahan bagi mereka dalam mencari penumpang. 


\section{DAFTAR PUSTAKA}

Budyatna, M. (2009). Metode Penelitian Sosial. Bandung : Refika Aditama.

Garna K. Judistira. (1996). Ilmu-Ilmu Sosial. Bandung : Program Pascasarjana Unisversitas Padjadjaran

Ibrahim Subandy Idi. (1997). Ecstasy Gaya Hidup. Bandung : Mizan

Jurdi Syarifuddin. (2013). Sosiologi Nusantara. Jakarta : kencana Prenada Media Group.

Mardalis. (2007). Metode Penelitian, Suatu Pendekatan Proposal. Jakarta : Bumi Aksara.

Martono Nanang. (2012). Sosiologi Perubahan Sosial. Jakarta : Rajawali Pers.

Narkowo J. Dwi dan Suyanto Bagong. (2011). Sosiologi Teks Pengantar. Jakarta : kencana Prenada Media Group.

Paul Johnson Doyle. (1986). Teori Sosiologi Klasik dan Modern. Jakarta :Gramedia.

Soerkanto Soerjono. (2009). Sosiologi Suatu Pengantar. Jakarta : Rajawali Pers.

Soekanto Soerjono. (1983). Teori Sosiologi Tentang Perubahan Sosial. Jakarta : Ghalia Indonesia.

Sztompka Piotr. (2011). Sosiologi Perubahan Sosial. Jakarta : Prenada.

Tim Penyusun FKIP Unismuh Makassar. Pedoman Penulisan Skripsi. Panrita Pers Unismuh Makassar.

Tim Prima Pena. (2006). Kamus Ilmiah Populer. Gitamedia Press.

Wirawan, I.B. (2012). Teori - Teori Sosial Dalam Tiga Paradigma. Jakarta : Kencana Prenada Media Group.

Weiner Myron. (1980). Modernisasi Dinamika Pertumbuhan. Yogyakarta : Gadjah Mada University Press.

Sucyhandayani Annysa. (2014). Dinamika Konflik Terminal Bayangan Jatibening (Studi Kasus: Konflik PT Jasa Marga Dengan Warga Terkait Dengan Penutupan Terminal Bayangan Jatibening di ruas Tol Jakarta-Cikampek). Tidak diterbitkan: Universitas Gadjah Mada. 